\title{
STUDY ON THE REPRODUCTION OF "LAYANG DELES" SHORTFIN SCAD (Decapterus macrosoma) IN THE JAVA SEA
}

\author{
Suherman Banon Atmaja") and Bambang Sadhotomo*)
}

\begin{abstract}
Some reproduction aspects of "layang deles" (Decapterus macrosoma) in the Java Sea were investigated using microscope, gonado somatic index and diameter of eggs for determining the stage of maturity. The distribution of gonado somatic index by size class showed that median value is always close to zero and $75 \%$ of the index value do not reach $2.5 \%$. According to the diameter of eggs, gonado somatic index value less than $4 \%$ was grouped into immature stage. The fish with mature stage in purse seine catches were purely coincidence, most of the time they were immature and reproductively inactive. The monthly development of gonado somatic index indicated that only single peak occurred in May and June. However, observation on the spent females indicated that spawning season occurred during the South-East monsoon (August-November). Spawning season most probably occurred within this time (May-November). Length at first maturity was 19.7 $\mathrm{cm}, \mathrm{FL}$. The batch fecundity is estimated between 43 to 88 thousands eggs. The average diameter of the mature eggs varied from 0.67 to $0.70 \mathrm{~mm}$. This species seems to spawn along the continental slope of eastern part of the Java Sea.
\end{abstract}

KEYWORD: $\quad$ scad, Decapterus Macrosoma, reproduction, Java Sea

\section{INTRODUCTION}

The pelagic fisheres in the Java Sea have developed rapidly since the mid 1970's, after the introduction of the purse seine fleet and the trawl ban in 1980. This fleet became the sole semi industrial exploitation in these waters. Numerous trawlers were transformed into purse seiners. In 1982/1983, the fleet extended their fishing ground towards the eastern part of the Java Sea and the southern part of the South China Sea. This extension was made easier by the introduction of bigger vessels (80-100 GT). In $1986 / 1987$, fishing tactic changed, light was replaced fish agregating device (FAD, rumpon) (Atmaja \& Sadhotomo, 1985; Potier \& Sadhotomo, 1995a).

At least four species of scads were found in Indonesian waters, i.e., Decapterus kurroides, Decapterus macarellus, Decapterus russelli, dan Decapterus macrosoma. In the southern part of the Sunda shelf, the last two species were the main components of small pelagic resources. They represented up to $60 \%$ of the catch in eastern part of the Java Sea (Potier \& Sadhotomo, 1995a). Before the introduction of the purse seiners in the Java Sea, Decapterus russelli was commonly caught by danish seine fishery (Potier \& Sadhotomo, 1995b). Concerning with frequency of occurrence of species in the fishing zones, Decapterus macrosoma was grouped into the fish which like oceanic habitat (Sadhotomo \& Durand, 1997). The landings increase significantly since the fishing grounds have been extended eastward. The monthly landings peaked obviously from October to April (Atmaja, 1999).

Preliminary studies on reproductive biology had been pioneered by Delsman (1926) on the early life stage and De Jong (1940) on eggs size distribution of some pelagic species. De Jong concluded that only one batch of eggs in the ovary and after spawning the ovary resembles empty of sack. Hardenberg (1938) gave an hypothesis on the distribution of scads populations Decapterus spp. in the Java Sea. He stated that there were three populations of scads inhabit the Java Sea waters, one from the east entering the Java Sea from Flores Sea during the South East monsoon and the other two populations coming from the west during the North West monsoon via the Indian Ocean then enters the Java Sea through the Sunda Strait and from South China Sea one through the Karimata Strait. Part of the eastern population residents in the Java Sea and its spawning grounds were near to the Bawean Island. Venema (1996) stated that scads spawn along the continental slope of the Java Sea. Widodo (1989) stated that the increases in the exploitation rate will lead to the recruitment overfishing, the size at first capture (Lc) being longer than the size at first maturity (Lm). The individuals that inhabit the Java Sea waters were being inactive stage of reproduction (Atmaja et al., 1995)

The present study described and clarified the reproduction of Decapterus macrosoma in Java Sea through the analysis of the scad landings by purse seine net, including stage of maturity, spawning season, size at first maturity, and fecundity.

\section{MATERIALS AND METHODS}

\section{Materials}

Data of reproduction aspects were collected at several landing places, i. e., Pekalongan, Juana, Rembang, and Sarang (Central Java), Kota Baru (South Kalimantan), Indramayu (West Java) during

\footnotetext{
*) Research Institute for Marine Fisheries, Ministry of Marine Affairs and Fisheries Muara Baru, Jakarta
} 
period of 1992-1995 and Labuan (West Java) from April-May 1998. This was part of the reseach activities of Research Institute for Marine of Fisheries and Java Sea Pelagic Fishery Assessment Project. The specimens were collected from the landings of commercial purse seine fishery and they were coming from all the main fishing grounds in the Java Sea.

\section{Methods}

\section{The stage of maturity}

The stage of maturity is adapted from several studies with differences species and ecological areas, because of inavailibilty of intensive investigation carried out in the Java Sea. We modified the criteria of Sardinella longiceps (Raja, 1967), Clupea harengus (lles, 1984; Hempel, 1979), Sardinella aurita (Fontana, 1969) and manual of biological observation (Holden \& Raitt, 1974). Then, maturity staging by Gonado Somatic Index was confirmed by microscopic examination, i. e., egg size. The index denoted as Gonado Somatic Index indicate a primary reproductive effort in fish and to reflect the development of the ova, i. e. stage of maturity. It was calculated as percentage of the gonads weight over somatic weight, as expressed in the following formula (lles, 1984):

$$
G S I=W g /(W b-W g) \times 100
$$

where:

$$
\begin{aligned}
& W_{g} \text { and } W_{b}= \text { he gonads and body weight } \\
& \text { respectively. }
\end{aligned}
$$

\section{Length at first maturity}

Sampling procedure, length composition of biological samples can be adjusted using length data which was regularly obtained by measuring the sampling. In each length group, for easily distinguishable fish, five individuals were chosen for a biological study. The sex was determined by dissection and examination of the gonads. The maturity stage, gonad weight, were recorded. A total of 2,250 specimens of a size longer than $13 \mathrm{~cm}$ was collected.

Length at first maturity was estimated by performing mean length of which the female individual considerably mature. This estimation would be analog as the length at which $50 \%$ of the fish are mature. The term of length at first maturity is commonly used in the context of population dynamics and estimated from cummulative frequency distribution. The definition of mature for various literatures were based on different criteria. In order to avoid subjectivity of staging and ambiguity of criterium used for mature fish, it is preferable to use the values of Gonado Somatic Index higher than 4\%. Sadhotomo (1998) in a study on small pelagic caught by the purse seiners, determined the ovaries as mature when Gonado Somatic Index was higher than $4 \%$. This value of Gonado Somatic Index has showed the ovary occupy almost the whole body cavity, abdomen distended.

\section{Fecundity}

Fecundity is defined here as the total number of ripe ova present in a female immediately prior to spawning, there is only a single batch of mature eggs (translucent eggs), sharply separated with smaller eggs stock (opaque eggs) as called batch fecundity (De Jong, 1940; Fontana 1969). Pried \& Walsh (1991) stated that batch fecundity is the number of hydrated oocytes released in one spawning, usualy determined by counting the number of hydrated oocytes in the ovary. The estimation of the number of eggs in the last mode was calculated from subsamples of the ovary with eggs diameter larger than $0.5 \mathrm{~mm}$. The subsamples were between 0.1 to $0.3 \mathrm{~g}$, measured and counted with 2 or 3 replications. The subsamples were counted under a binocular microscope, with 100x. The batch fecundity was determined by gravimetric method (Bagenal, 1978a), which was estimated by the following equation:

$$
F=(W g M s) \cdot n
$$

where:

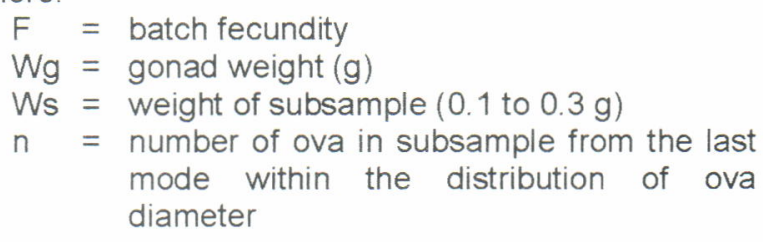

\section{RESULTS}

\section{Distribution of Gonado Somatic Index}

\section{Sexual maturity}

Often in fisheries work only the female ovaries are studied, because these are larger and more easily examined than male testes, it also assumed that development of both ovaries and testes are synchronous. Ovaries may be examined microscopically and classified into various developmental stage. The particular event of interest in the reproductive cycle of a species is the time spawning, when fully developed gametes are released (King, 1998)

For the sake of uniformity of staging criteria used in this study, it emphasizes on the use of for the sake of uniformity of staging criteria used in this study, it emphasizes on the use of for the sake of uniformity of staging criteria used in this study, it emphasizes on the use of Gonado Somatic Index rather than the stage of maturity. However, visual observations were done by three people (of the biology team of the Pelfish Project) and several university students that 


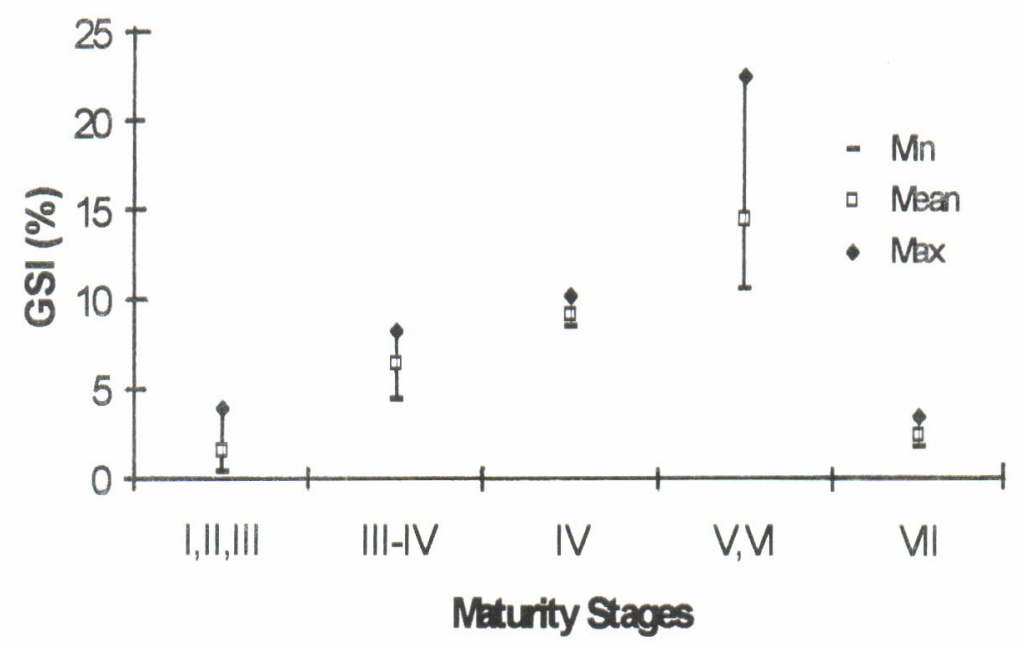

Figure 1. Relationships between Gonado Somatic Index (\%) and maturity stage of Decapterus macrosoma, with maximum and minimum.

possibly generates a subjectivity of observation in different landing places. Structure of maturity stage of female fish was evaluated using Gonado Somatic Index and a verification for its relationship was depicted in Figure 1. The value of Gonado Somatic Index of the stages IV and V, VI were $8.5-10.2 \%$ and $10.6-22.6 \%$ respectively. Linkage between Gonado Somatic Index, macroscopic and microscopic for ripe and spawning stages (Figure 2). Ripe stage was characterized by ovaries which contain opaque eggs. According to the diameter of these eggs, Gonado Somatic Index values range from $4 \%$ to over $6 \%$. Spawning stage was characterized by a fish with distended abdomen, a peritoneal cavity filled with ovaries where translucent eggs are visible through the ovary. This phenomenon is very common in the development of ovaries and usually most species have transparent eggs to reduce the predation (Johannes in Bailey \& Houde, 1989). The weight of gonad for stage VI represent $19.8-22.9 \%$ of the weight of the fish in Clupea harengus (lles, 1984). The average of Gonado Somatic Index in stage VI of Scomber scombrus (Morse, 1980) and Engraulis mordax (Laroche \& Richardson, 1980) were $24.9 \%$ and $18.1 \%$, respectively. In the current study the average of Gonado Somatic Index in stages $\mathrm{V}$ and $\mathrm{VI}$ were $14.64 \%$.

\section{Distribution of Gonado Somatic Index by length}

More than $40 \%$ of the individuals fish of size $15 \mathrm{~cm}$ $(F L)$ were sexually undetermined. At $16 \mathrm{~cm}$ long, this percentage decreases to only $30 \%$ of undetermined. This size corresponds to the one found by Widodo (1988; 1991a; 1997) for the first maturity (Lm) (Figure 3a). He gave a size at first maturity of $15.5 \mathrm{~cm}$.

The distribution of value of Gonado Somatic Index by length class for females can be seen in the Figure $3 b$. Figure $3 b$ showed the distribution of Gonado Somatic Index values by size class (FI) through Box \&
Whisker Plots (Tukey, 1977). The range of the Gonado Somatic Index increases with the size reaching a peak at $19 \mathrm{~cm}$. Median value is always close to zero and $75 \%$ of the values do not reach $2.5 \%$. It can be stated that the fishes with mature stage (GSI>4\%) scarecly in sample, indicating an incidental occurring the mature stage in purse seiner catches.

\section{Spawning season and places}

Based on period of occurrence highest average value, monthly evolution of Gonado Somatic Index demonstrated only one peak a year (Figure 4). This would indicate that spawning season during the periods of observation, although some peaks that clearly shown in the figure came from few specimens only. Unfortunately, there is no information on the development of Gonado Somatic Index from imature stage to spawning stage that enable us to classify the group of spawner for the next spawning. More precisely, the occurence of spent specimens would give a direct indication of spawning season. Prediction of spawning season based on summarizing the occurence of spent specimens (Table 1). This showed that spawning season also occurred in most of the months between July and November.

However, based on back calculation of age of juvenile fish entering the fishery at begining recruitments (Table 2), showing that this species also spawned in January-March.

Ripe stage specimens were found in July 1992 and May-June 1993 in the sub area Matasiri-Samber geleng Bank, while the spent ones (partly and fully) were frequently found in July-August in the more extensive sub areas i. e. Bawean-Lumu-Iumu Bank in the southern most of Makassar Strait (Table 3). A preliminary conclusion can be drawn for spawning behaviour of Decapterus macrosoma. It appears that spawning takes place in the near slope ground or probably beyond the Java Sea. 

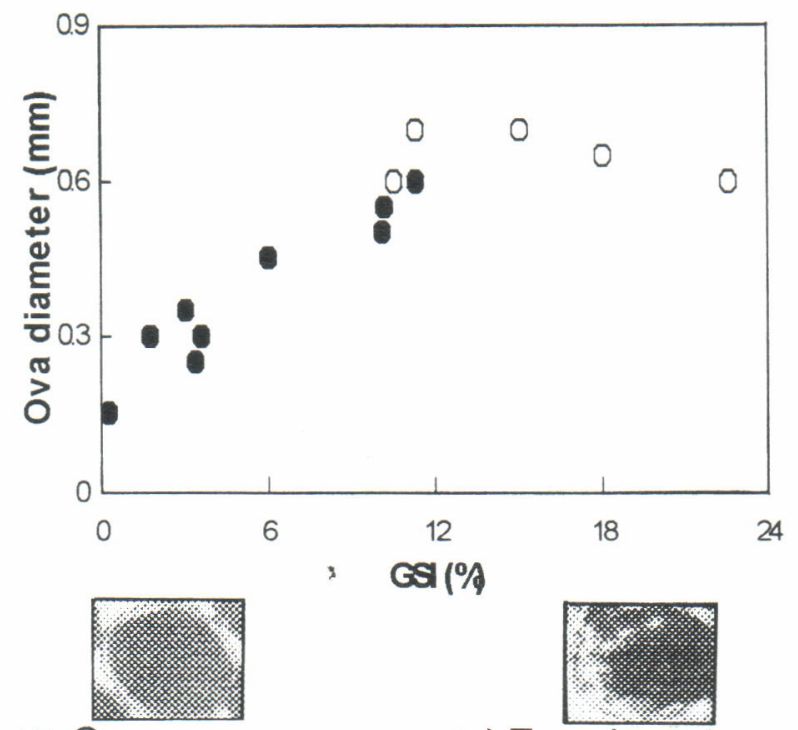

(•) Opague eggs

(o) Translucent eggs

Figure 2. Plot eggs diameter and Gonado Somatic Index (\%) value of scads.

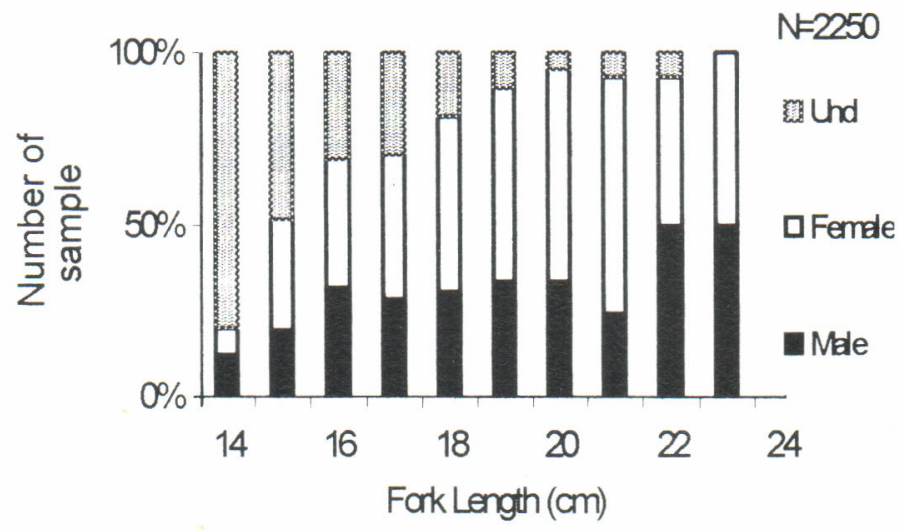

Figure 3a. Percentage of male (below), females (center), and undetermined individuals (above) by class size $(\mathrm{cm})$.

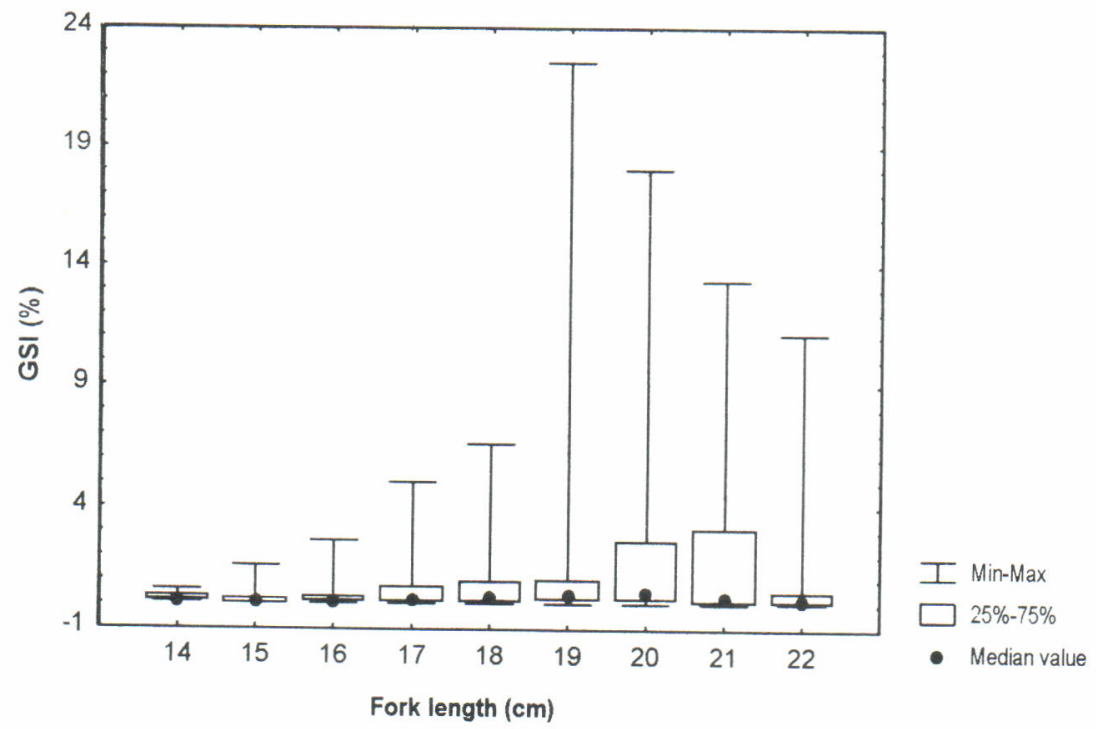

Figure 3b. Distribution of Gonado Somatic Index (\%) value of Decapterus macrosoma by size $(\mathrm{cm})$. 


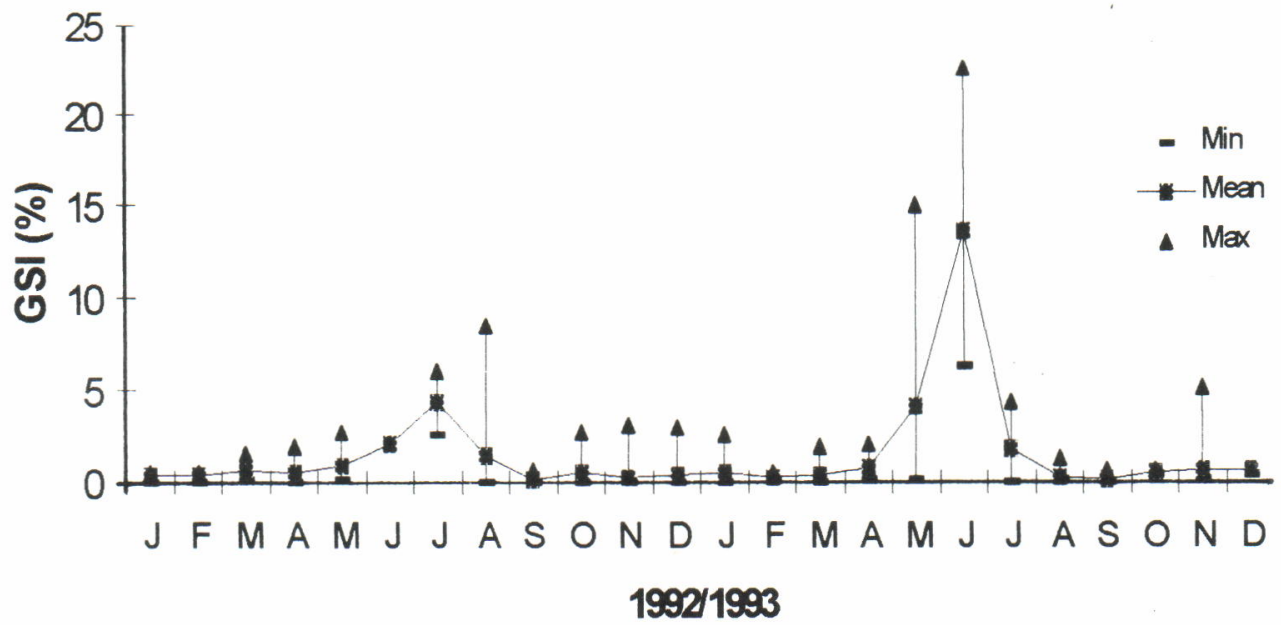

Figure 4. Monthly evolution of Gonado Somatic Index values of the main species in the Java Sea, 1992/1993.

Table 1. Monthly distribution of maturity stages (\%)

\begin{tabular}{|c|c|c|c|c|c|c|}
\hline Month/Stages & I, II, III & III, IV & IV & $\mathrm{V}, \mathrm{VI}$ & VII & $\mathbf{n}$ \\
\hline January & 100 & & & & & 227 \\
\hline February & 100 & & & & & 137 \\
\hline March & 100 & & & & & 92 \\
\hline April & 100 & & & & & 52 \\
\hline May & 94.5 & & & 5.4 & & 56 \\
\hline June & 78.5 & 3.1 & 3.1 & 15.4 & & 65 \\
\hline July & 60.5 & 30.4 & & & 8.3 & 23 \\
\hline August & 84.4 & 13.0 & 1.3 & & 1.3 & 77 \\
\hline September & 93.0 & & & & 6.9 & 29 \\
\hline October & 97.9 & 1.0 & & & 1.0 & 97 \\
\hline November & 96.5 & 0.8 & & & 2.3 & 130 \\
\hline December & 100 & & & & & 74 \\
\hline
\end{tabular}

Table 2. Approximates spawning season of Decapterus macrosoma as back calculated from length at the first period of entering the fishery (underlined figures are derived from minor distribution) (Sadhotomo, 1998)

\begin{tabular}{lcl}
\hline $\begin{array}{c}\text { Approximates spawning } \\
\text { periods }\end{array}$ & Modes of length $\mathbf{( c m )}$ & \multicolumn{1}{c}{ Periods of observation } \\
\hline August 1991 & 8.5 & November 1991 \\
January 1992 & 12.5 & July 1992 \\
January 1993 & 11.5 & June 1993 \\
February 1994 & 12.5 & June 1994 \\
August 1994 & 10.5 & November 1994 \\
March 1995 & 9.5 & June 1995 \\
\hline
\end{tabular}

Table 3. Maturity stages and Gonado Somatic Index (\%) classification by fishing ground

\begin{tabular}{|c|c|c|c|c|c|c|}
\hline Zones/Stages & I, II, III & III, IV & IV & V, VI & VII & $\mathbf{n}$ \\
\hline Labuan & 98 & 2 & & & & 80 \\
\hline Indramayu & 100 & & & & & 20 \\
\hline Karimunjawa & 99.4 & 0.6 & - & - & - & 154 \\
\hline Bawean & 96.9 & 1.1 & - & - & 2.1 & 96 \\
\hline Masalembo & 93.8 & 3.4 & - & 1.4 & 1.4 & 208 \\
\hline Matasiri-Samber geleng & 92.5 & 1.9 & 0.7 & 3.7 & 1.1 & 268 \\
\hline Lumu-Iumu & 94.8 & 4.3 & 0.5 & - & 0.5 & 211 \\
\hline Kangean & 100 & - & - & - & - & 112 \\
\hline
\end{tabular}




\section{Size at first maturity}

Estimation of the mean length of the mature female was derived from the frequency distribution of the mature female ( $\mathrm{GS} \mid>4 \%$ ). The female would reach maturity at $19.7 \mathrm{~cm}$ in average of fork length (Figure $5)$. In the Philippines waters, this species matures at length of $18-20 \mathrm{~cm}$ at the beginning of the third year of life (Tiews et al., 1970). They also suggested that Decapterus macrosoma spawns only once in its life span.

\section{Sex Ratio}

The proportion of female seems to vary by month. Proportions of females of Decapterus macrosoma tended to pass the males almost all year (Figure 6). There is no significant conclusion to extract from this figure without evaluating reproductive behaviour and the relationship between female stock and successive recruits.

\section{Fecundity}

Due to the lack of mature sample found within current observation data, the fecundity was evaluated from a few specimens (i. e. only 10 specimens), where the ovaries with eggs ready to be spent or exactly in ripe stage. In this stage, there is only single batch of mature eggs found in the ovary sharply separating from the immature ones. The mature eggs are easily differentiated from the smaller opaque ova (immature ones) and their size vary from 0.50 to 0.90 $\mathrm{mm}$ in diameter (Figure 7). Immediately, after spawning (spent or partly spent stages) the ovaries still contain some residual transclucent and the immature eggs. These unshed eggs will be reabsorbed into ovarian tissue as shown by opaque eggs in some spent stage specimens. Pried \& Walsh (1991) first point out that the fish release eggs in discrete batches rather than continously. Is suggests that this species never spawns more than once in a year. After spawning, the fish usually do recovery that can be shown by large size (more than $21 \mathrm{~cm}$ ) in resting stage or in inactive condition. The average of fecundity estimated to be 61,200 eggs per batch of female fish with the range values of $43,000-88,000$ (Table 4 and Figure 8).

The fecundity seems to be lower than that in the Philippines waters that counted to be in the range of 68,000 to 106,000 eggs per female (Tiew, et al., 1970). Unfortunately, its relation to the body size is not clear due to the narrow range of the size of the

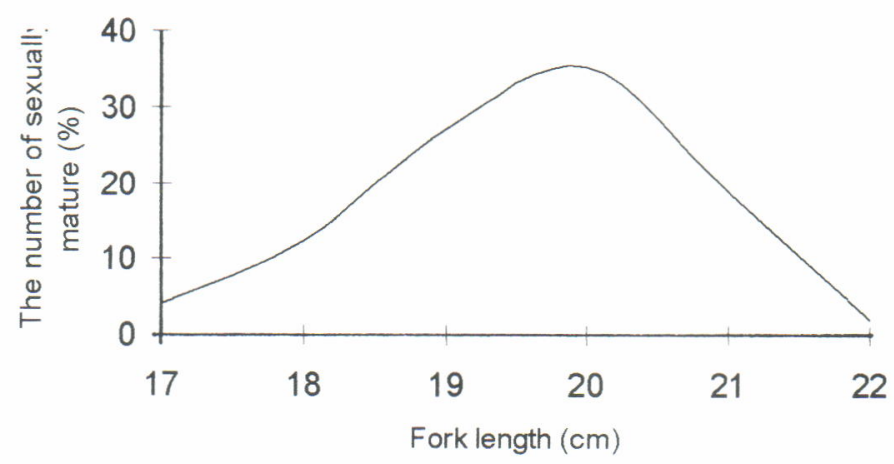

Figure 5. Length frequency of female scads by GSI value $>4 \%$

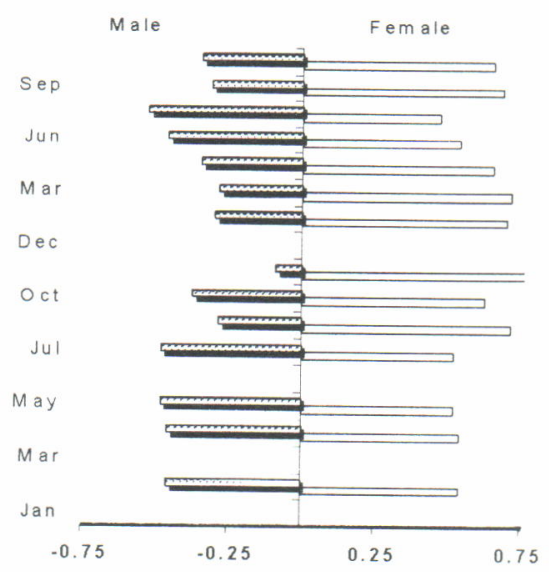

Figure 6. Proportion of sex of Decapterus macrosoma. 
Table 4. Summary of the ten specimens $(n=10)$ for fecundity observation

\begin{tabular}{lcccc}
\hline & Mean & Minimum & Maximum & Std.deviation \\
\hline FL $(\mathrm{cm})$ & 20.06 & 19.3 & 20.5 & 0.45 \\
GSI $(\%)$ & 14.64 & 10.6 & 22.6 & 3.70 \\
FECUNDITY & 60,378 & 43,000 & 80,000 & 1,289 \\
\hline
\end{tabular}

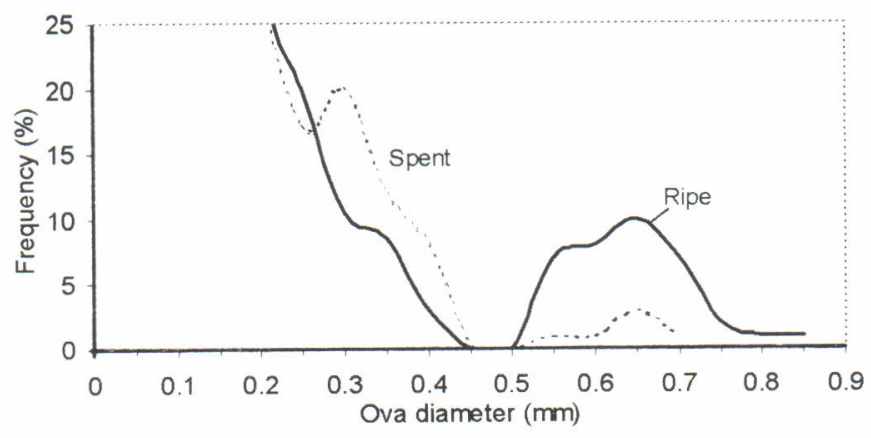

Figure 7. Eggs size distribution of mature stage of Decapterus macrosoma.
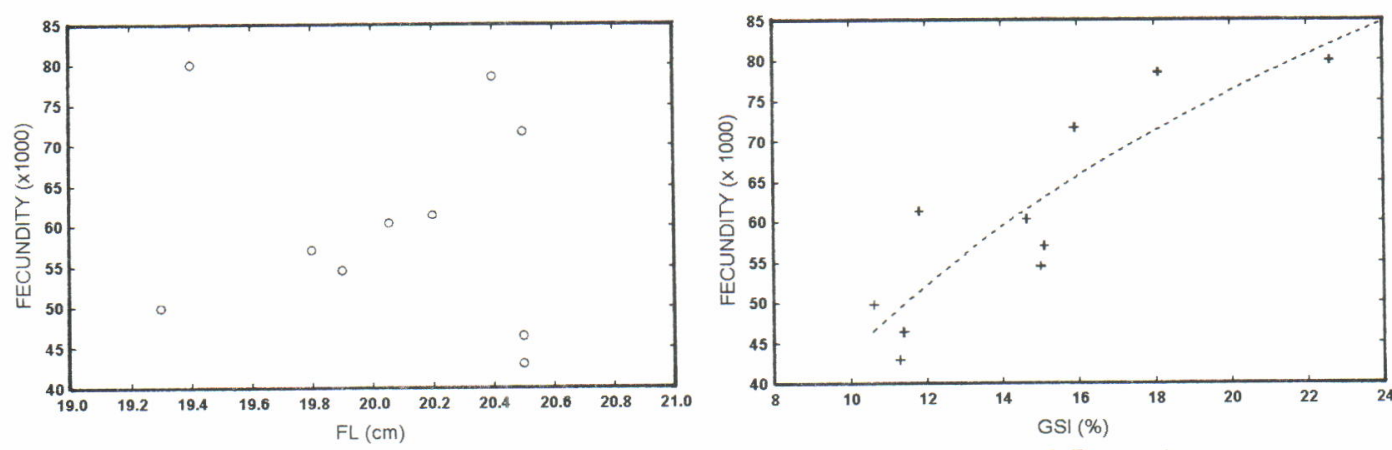

Figure 8. Plot of fecundity versus length and Gonado Somatic Index of Decapterus macrosoma

specimens (i. e. $19.5-20.5 \mathrm{~cm}$ in fork length). The mature eggs (translucent eggs) were mode with a diameter variation of $0.50-0.90 \mathrm{~mm}$.

\section{DISCUSSION}

Staging criteria used in this study was confirmed by the relative size of the ovaries and visual performance of the ova. In stage $V$ and $\mathrm{VI}$, the ovaries occupy almost the whole of body cavity and eggs are translucent. Visual examination show an abdomen distended, the whole peritoneum cavity is filled with ovaries and translucent eggs became easily visible through the ovary wall. In this stage also part of the ova is ready to spent and the Gonado Somatic Index value will attain maximum (Figure 1) as well as the ova size (Figure 2). While the difference with the observation of Widodo (1988; 1991a) was probably due to the different visual determination. However, it could not infer that different population may have different reproductive charateristic since the criteria and the composition of samples by length (age) used are not comparable. It believes that his study was not including the ovary with translucent eggs (stages $\mathrm{V}$ and $\mathrm{VI}$ ).

The size at first maturity appear slightly lower than the result of previous studies from Atmaja et al. $(1995)^{2}$. On the other hand, Widodo (1991a; 1991b; $1997)^{3}$ estimated the length at first maturity to be much lower than others eventhough the criteria of staging are almost same. Apparently, microscopic verification is needed for determining the mature condition but this procedure is time consuming. For this reason we used transclucent eggs for mature criterium of female of this species. In this case, subjectivity of observation plays an importance role in influencing the final results, more than the methods applied.

Prediction of spawning season based on summarizing three methods (monthly evolution of Gonado Somatic Index, the occurence of spent specimens and based on back calculation of age of juvenile fish entering the fishery at begining recruitments), if these methods were mutually suplement. A conclusion can be drawn that 
Decapterus macrosoma spawns all year, but juvenille fish entering the fishery at the begining of recruitments.

Difficulty of finding the mature fish inside the Java Sea (in the area covered by this study) would immediately reveal conclusion that this area is not the spawning ground of this species, or at least this species do not spawn in the fishing ground of the purse seine. We found in our study similarly to De Jong (1940) who noted that ripe fishes are rarely found in the Java Sea even during spawning season. In relation to recruitment and migration scheme, Sadhotomo \& Potier (1995) implicitely indicated a possible spawning ground of pelagic species (for the highly migrant species, such as Decapterus macrosoma) in the slope of eastern part of the Java Sea without giving any detail. However, this (hyphothesis) means that the most likely spawning ground would be outside of the Java Sea. Delsman (1926) showed an indication of spawning ground of layang (Decapterus russellii) near Bawean and Madura Islands in his mission on June 1920 and October 1922. His statement of observed of fully mature fish in fishermen catch could be unreliable indication for spawning ground as there was no direct observation had been made for determining the maturity. Also, eggs and larvals stages specimens found in that subarea might be misidentified as Caranx kurra and Caranx macrosoma (synonim of Decapterus russellii and Decapterus macrosoma). $\mathrm{He}$ speculatively used reference of Trachurus trachurus for the genus Caranx (Decapterus) and other genus of Carangidae (that recently identified as genus of Caranx, Atule, and Alepes).

However, a highly seasonal availability of samples in the period before development of purse seine could cause a difficulty in conducting a continous observations on pelagic species in the Java Sea. However, the phenomena of simultaneous spawning season as indicated in almost the same period of the occurence of the highest average of Gonado Somatic Index of the main species could not be used for corroborating the Delsman's specimens. But, in this case, one could say that the hydrological condition at that time was better than that of current period. Of course, it is a little bit nostalgic, but, it has been well known, there was no extractive exploitation on coral reef and detruction of the habitat before decade 1960's (Subani, 1972).

A question of possibility of occurence of spawning ground in the Java Sea in past time would relate to disappearence of substock due to heavy exploitation and the change of reproductive behaviour. Unfortunately, we could not go any further because of the lack of information. Theoretically, an ideal condition in the past (say 30 years ago) can be said as analog with concept of optimal environmental window of Cury \& Roy (1987). Adapting the theory of Gargett (1997), the Java Sea area at that time could be regarded as an area with an optimal window during intermediate stabilities that is a range of stability value for which the associated condition of sea waters (nutrient and others) are sufficient, stimulating levels of primary production which are significantly larger than those of other period. Then, we could speculate that before the tremendously increase of fishing effort being started in the 1970's decade, the Java Sea stock might be composed by several subpopulations, more than those at recent years. Anyway, the Java Sea is not closed to other neighboring areas and migration of larval and nekton stage could be possible following seasonal circulation scheme of sea.

\section{CONCLUSION}

In general, the fish stock available for the fisheries mainly consist of young fishes. Very few specimen of adult fish indicated that Decapterus macrosoma was not available in the fishing ground, all year around.

Two groups of recruits were identified in the Java Sea. The major recruits enter the fisheries during the southeast monsoon (June-July) and the minor one during November. From back calculation of the age of youngest groups of the major recruits, we can conclude that these recruits were not the offsprings descended by the adult fishes stayed in this area in last year period. The peak of maturity of the fishes staying in the Java Sea occurs in June-July, and peak spawning season would be on July-November, while the approximate spawning of the major recruits was about November. The scarce of ripe and spawning stage specimens in the samples indicate that the spawning grounds of this species was not in the Java Sea ( $i$. e. at least this was not in the fishing ground of the purse seine fleets).

\section{ACKNOWLEDGMENT}

We wish to thank Mr. Michel and Mr. Francois for helpful cristicisms and reading this paper.

\section{REFERENCES}

Atmaja, S.B. 1999. Variasi geografis hasil tangkapan ikan layang (Decapterus spp.) di perairan bagian selatan Paparan Sunda. Jurnal Penelitian Perikanan Indonesia. Vol.V (3): 63-71.

Atmaja, S.B. \& B. Sadhotomo, 1985. Operational aspects of purse seine fishing in the Java sea. Mar. Fish. Res. Report. Jakarta. 32: 65-71.

Atmaja, S.B., B. Sadhotomo, \& Suwarso. 1995 Reproduction of main small pelagic species in the Java Sea. In Potier \& Nurhakim (Eds.), Biology, Dynamic and Exploitation (BIODYNEX). AARD/ORSTOM. 69-84. 
Bagenal, T. 1978a. Aspects of fish fecundity. In Gerking, S.D. (Eds.). Ecology of fresh water fish production. Oxford, Blackwell. 75-101.

Bailey K.M. \& E.D. Houde. 1978. Predator on eggs and larvae of marine fishes and the recruitment problem. In Blaxter. J. H. S. \& A. J. Southward, (Eds.). Marine biology. Academic Press. London. Vol.25, 2-82

Cury, P. \& Roy, C. 1987. Upwelling et pêche de espèce pélagiques côtières de Côte d'Ivoire: un approch globale. Oceanologica Acta. 10 (3), 347357

Delsman, H.C. 1926. Fish eggs and larvae from the Java Sea 5. Caranx kurra, C. macrosoma, and C. crumenophthalmus. Treubia, 8 (3, 4): 199-211.

De Jong, J.K. 1940. A preliminary investigation of the spawning habits of the fishes of the Java Sea Treubia. 17, 307-330

Fontana, T. 1969. Etude de la maturité sexulle des sardinelles, Sardinella eba (Val) and Sardinella aurita ( $C$ et $V$ ) de la region Pointe-Noire. Cah. ORSTOM (Sér. Oceanogr). 7 (2): 101-114.

Gargelt, A.E. 1997. The optimal stability window: a mechanism underlying decadal fluctuation in North Pacific Salmon stock?. Fish. Oceanogr. 6 (2): 109117

Hardenberg, J. D. F. 1938. Theory on the migration of layang (Decapterus spp.) in the Java Sea. Med Inst. Zeevisscherij, Batavia. 124-131.

Hempel, G, 1979. Early life history of marine fish (the egg stage). Washington Sea Grant Publication. Seattle. $79 p$.

lles, T.D. 1984. Allocation of resources to gonad and soma in Atlantic Herring, Clupea harengus L. In Potts, G. W. \& R. J. Wooton (Eds). Fish Reproduction, Strategies and tactics, Academic Press, London. 322-347

Holden, M.J. \& D.F.S. Raitt. 1974. Manual of fisheries science part 2. Methods of resources investigation and their application. FAO. Fish. Tech. Pap. Rev, $214 p$

King, M. 1998. Fisheries biology, assessment, and management. Fishing New Books. England. 338p.

Laroche, J.L. \& S. Richardson. 1980. Reproduction of Nothern Anchovy, Engraulis mordax off Oregon and Washington. Fish. Bull. U.S. Vol.78 (3): 603618

Morse, W.W. 1980. Spawning and fecundity of Atlantic Mackerel, Scomber scombrus in the
Middle Atlantic Bright. Fish. Bull. U.S. Vol.78 (1) 103-108

Potier, M. \& B. Sadhotomo. 1995a. Exploitation of the large and medium seiners fisheries. In Potier \& Nurhakim (Eds.), Biology, Dynamic and Exploitation (BIODYNEX). AARD/ORSTOM, 195214

Potier, M. \& B. Sadhotomo. 1995b. Trends in the scad fishery of the Java Sea Exploitation of the large and medium seiners fisheries. Fourth Asian Fisheries Forum, Beijing: 16-20 October 1995.

Potier, M. 1998. Pêcherie de layang et senneurs semi industriels Javanais: Perspective historique et approche système. Phd Thesis, Université de Montpellier II, 280p.

Pried, I.G. \& M. Walsh. 1991. Estimation of biomass of Atlantic Mackerel (Scomber scombrus) using the annual and daily egg production methods. Progess and problem in fish abundance estimation. ICES. $19 p$

Raja, B.T.A, 1967. Some aspects of spawning biology of indian oil sardine, Sardinella longiceps Val. Indian. Journalis Fisheries. 11A (1): 45-120.

Sadhotomo, B. \& M. Potier. 1995. Exploratory scheme for recruitment and migration oí main pelagic species in the Java Sea. In Potier \& Nurhakim (Eds.), Biology, Dynamic and Exploitation (BIODYNEX). AARD/ORSTOM. 155-184

Sadhotomo \& J.R. Durand. 1997 General Feature of Java Sea Ecology. In Petit, D., P. Coted \& D. Nugroho (Eds). Akustikan 2 Proceedings at acustics Seminar Akustikan 2 AARD/EEC/ORSTOM: 43-45.

Sadhotomo, B. 1998. Bioécologie des principales espèces pélagiques exploitées en mer de Java. Phd Thesis, Université de Montpellier II. 364p.

Subani, W. 1972. Fishing gear and method (in Indonesia). Lembaga Penelitian Perikanan Laut. Jakarta.

Tiew, K., I.A. Ronguillo, \& P. Caces-borj. 1970. On biology of round scads (Decapterus spp. Bleeker) in the Philippines waters. Proccedding IPFC. 13 (2), 82-106

Tukey, J.W. 1977. Exploratory data analysis. AddisonWesley, Reading, Massachusetts.

Widodo. J. 1988. Population dynamics and management of ikan layang, scad mackerel, Decapterus spp. (Pisces Carangidae) in the Java Sea. PhD Disertation School of Fisheries, University of Washington, Seatlle. 150p 
1989. Prelimery assessment of effects of changes in size limit and fishing intensity on small pelagic multispecies in the Java Sea. J. Mar. Res. Inst. 51: 67-78.

1991a. Maturity and spawning of shortfin scad (Decapterus macrosoma, Carangidae) of the Java Sea. Asian Fish. Sci. 4: 245-252.

1991b. Konsep F0.1 sebagai strategi pengelolaan sumber daya ikan layang, Decapterus spp. di Laut Jawa. Jurnal Penelitian Perikanan Laut. 64: 1-6.
1997. Review of small pelagic fisheries of Indonesia. In Devaraj, M. \& P. Martosubroto (Eds.). Small pelagic resources and their fisheries in the Asia-Pacific region. Proceeding of APFIC Working Party on Marine Fisheries, 13- 16 May 1997. Bangkok, Thailand. RAP Publication. 1997/31. 199-226

Venema, S.C. 1996. Result of surveys for pelagic resources in Indonesian waters with the R/V Lemuru, December 1972 to May 1976. In Pauly \& Martosubroto (Eds.). Biodiversity the fish resources of western Indonesia. ICLARM Rev., 23 : 102-122 